\title{
Semiotic Representations of the Linear Function by Students Studying Administration
}

\author{
Julio C. Ansaldo-Leyva ${ }^{1}$, Julia X. Peralta-García ${ }^{1}$, Francisco J. Encinas-Pablos ${ }^{1}$, Omar Cuevas-Salazar ${ }^{1}$, \\ Laura Rangel-Lucas ${ }^{1} \&$ Noelia Londoño-Millán ${ }^{2}$ \\ ${ }^{1}$ Instituto Tecnológico de Sonora, Sonora, Mexico \\ ${ }^{2}$ Universidad Autónoma de Coahuila, Coahuila, Mexico \\ Correspondence: Francisco J. Encinas-Pablos, Instituto Tecnológico de Sonora, Calle Antonio Caso S/N. Colonia \\ Villa ITSON. Cd. Obregón, Sonora, Mexico.
}

Received: November 1, 2018

Accepted: June 1, 2019

Online Published: August 29, 2019

doi:10.5539/ies.v12n9p97

URL: https://doi.org/10.5539/ies.v12n9p97

\begin{abstract}
Mathematical tools allow us to clearly explain the phenomenon studied in administrative science. Various studies have shown that linear function is a concept, widely used in administration, as well as in other kinds of science, but difficult for students to grasp and assimilate as a tool in their studies. That is the reason that the objective of the present project was to determine the difficulties faced by students of administration in learning the concept of the linear function, based on the theoretical elements of Raymond Duval's registers of semiotic representation, to identify areas of opportunity in the teaching/learning process of this mathematical concept. Therefore, we designed an instrument made up of eight situations, which altogether consist of 24 problems. This instrument was validated by three experts in the area. Later, in keeping with the nature of the data to be collected, the instrument was given to a small randomly chosen sample group of six students studying under-graduate level administration and who were taking the subject of Mathematics for Business I. Students had the most difficulty in dealing with the registry of graphic representation and the cognitive activity of conversion between graphic and algebraic registers. It was also discovered that apparently context problems favored the latter conversion activity. We recommend these findings be further studied in a didactic approach to the issue, as well as carrying out studies of this nature on other mathematical objects in the course.
\end{abstract}

Keywords: conversions of registers, linear function, semiotic representation

\section{Introduction}

Mathematics is of the upmost importance in the curricular development of university students. In the first place this is due to its formative nature which teaches students to reason and promotes creativity in problem solving and secondly because it is considered a tool which is applicable in many kinds of science and which contributes to better understanding in various disciplines (Ministerio de Educación, n.d.).

However, in Mexico students often have a hard time understanding mathematics at all educational levels. The PISA exam, for example, a standardized international exam which measures the advancement or lagging behind in education, has shown that secondary school students fall below satisfactory domination of mathematical objectives at this level (Márquez-Jiménez, 2017). Moreover, the results of the PLANEA (National Exam for the Evaluation of Learning) exam, a diagnostic evaluation in Mexico for the obligatory levels of education and high school, has made it clear many students who are to soon enter universities possess limited skills in Mathematics. This is evident by the fact that 66 per cent of the candidates in 2017 tested at the lowest level of the exam, a level below the requirement for studying at the university level (Secretaría de Educación Pública, 2018).

Based on the results of standardized tests in education in Mexico it is to be expected that most students entering university show less than desirable performance in mathematics. For example, in the subject which is the object of our research, Mathematics for Business I, taken by students in undergraduate studies in administration at the Instituto Tecnológico de Sonora, there is little comprehension of mathematical objects, proven by the fact that in the last two semesters the average grade has been 45 per cent. This brings about serious problems in the area of Administrative studies since for the Consejo de Acreditación de Ciencias Administrativas, Contables y Afines (n.d.) the percentage of passing grades and end efficiency are very important indicators. 
According to Amaya and Sgreccia (2014) various studies in the field of mathematical education have proved that students have persistent difficulties in the study and understanding of functions in general. Specifically, linear function which is one of the mathematical objects of study in the subject, "Mathematics for Business," has proven, through statistical evidence, that students have low levels of achievement in this subject. This negatively impacts learning other subjects in the course due to the various applications of linear functions necessary.

Various authors have made interesting contributions related to ways to overcome learning difficulties in mathematics. One of these contributions points out that a mathematical object should be taught and learned through problems within the context of science, professions and every-day life (Camarena, 2013; E. Trejo-Trejo, Camarena-Gallardo, \& N. Trejo-Trejo, 2013). These authors believe that problems within a given context awaken the interest of the students, providing a reason for learning and potentializing the transfer of mathematical objects.

Duval $(1993,2012 a)$ established that mathematical objects are not directly accessible to perception; they are not tangible objects; they require representations such as writing, a symbol, a line, a figure, among others to access them. However, the problems this causes are that mathematical objects are confused with their representations, creating a loss of understanding of mathematical knowledge and making it impossible to use them outside of the learning context. Therefore, it is necessary to distinguish between the mathematical object and its representation. This is the reason Duval believes that this distinction is an important element in understanding mathematics.

Semiotic representations are necessary because they are the only way of accessing mathematical objects. However, they must not be confused with the object. The former are not built by the perception or utilization of instruments but rather on the production of semiotic representations. That is to say, they are simply productions consisting of signs through which access may be made to objects.

It is necessary for objects to be represented by various forms or registers. These may be verbal, graphic, tabular, algebraic and symbolic, among others. Each register of a representation shows some of the features of the mathematical object and the rules for dealing with the mathematical object. The more representations are made of a given object, the easier it is to obtain a more extensive and profound understanding.

In order for systems of representation of mathematical objects to be registers of semiotic representation they must allow for three cognitive activities: the Formation of representations reached by means of identifiable signs in a specific register; the activity of the Treatment of a representation which is the transformation of this representation in the same register where it was formed and the Conversion of a representation which is the transformation of a representation to another register, conserving the totality or only part of the content of the initial representation (Duval, 1993, 2012b).

For this author the fundamental and all-important role constitutes the transformation of representations into others (Duval, 2006), so that the condition necessary for understanding the conceptual content in mathematics is the coordination of at least two registers of the semiotic representations. That is to say, the speed and spontaneity with which the cognitive activity of conversion takes place.

In the specific case of mathematical education, the theory of Register of Semiotic Representation has gained in popularity and shows the interest of the scientific community in using these concepts in the study of the processes of teaching and learning, either for diagnostic purposes or to analyze the effectivity of new proposals for teaching as reported by: Elia, Panaoura, Gagatsis, Gravvani, and Spyrou (2008), Díaz, Haye, Montenegro, and Córdoba (2013), McGee and Martinez-Planell (2014), Adu-Gyamfi and Bossé (2014), Amaya and Sgreccia (2014), Martínez, Sevilla, Fuentes, Rivera, and Ávila (2016), Prada-Núñez, Hernández-Suárez, and Jaimes-Contreras (2017), Tocto and Reaño (2017), Panaoura, Michael-Chrysantho, Gagatsis, Elia, and Philippou (2017), among others.

Based on all of this and in order to deal with the problem of learning the subject of linear function, the basic problem of our research was: what representations and cognitive activities are difficult for students of the subject of linear function?

Thus, the main objective of this research was stated in the following way: To determine the difficulties students of administration have in learning the concept of linear function, based on the theoretical elements of Raymond Duval's registers of semiotic representation used to identify areas of opportunity in the teaching-learning process of this mathematical object.

\section{Method}

\subsection{Kind of Study}

The qualitative research is aimed at delving deeper into the subject in order to understand the phenomenon, 
exploring them from the perspective of the participants in their natural environment and in relation to their context, and applied to fewer cases (Hernández, Fernández, \& Baptista, 2014). For our investigation information on the processes followed by the participants in answering and/or solving various problems related to cognitive activities of the Formation, Treatment and Conversion of semiotic registers of the linear function was collected (Duval, 1993, 2012b).

\subsection{Subjects}

Six students studying the subject of Mathematics for Business I given in the first semester of the Education Program for a bachelor's degree in Administration at the Instituto Tecnológico de Sonora participated in the study. Four of these were men and two women, ranging in age from 19 to 21 years old.

\subsection{Instrument}

A questionnaire with a total of 24 questions was used. Seven of these were presented within the intra-mathematical sphere, while the rest were problems related to the context of businesses; that is to say, problems related to the supply and demand of commercial products. The questions were presented in different registers of representation: algebraic, graphic and tabular, manipulating various cognitive activities.

Of the 24 questions, eight of the problems were designed to seek the participants' cognitive activity of Formation in the graphic and tabular registers. One example of this activity is the second question which gives data for the coordinates (x, y) as seven points, asking the student to place them on a Cartesian Plane. Another 11 questions were| designed with the intention of having the students carry out Treatment activity in all three registers. Question 12 is a clear example of the activity on a tabular register, giving as data the coordinates (x,y) for a couple of points and asking the student to calculate the slope of the straight line. The purpose of the remaining five questions was to have students carry out the cognitive activity of Conversion from a tabular to an algebraic register, from an algebraic to a graphic register and from a graphic to an algebraic register. Question 22 belongs to this group, giving the information on the graphic placement of a straight line, asking the student to determine its algebraic expression. In summary, the cognitive activity of Formation was evaluated with questions 1 through 8 ; Treatment in questions 9 through 19 and Conversion in questions 20 through 24.

The subject of evaluation was the linear function, through its semiotic representation: algebraic, graphic and tabular. It should be pointed out that for each problem enough space was given for the participants to write down the process they used for arriving at their answer, with the purpose of identifying the problems they had in using the various registers of semiotic representation.

\subsection{Procedure}

The first step consisted of making up 24 problems in keeping with Santibañez' (2011) suggestions for achieving validity in the content of the instrument. The problems or items were designed with the intention of having the students reflect on the cognitive activities of the Formation, Treatment and Conversion of semiotic representation of the linear function. Later, the instrument was evaluated by three experts in the area of the content in order assure that the exam evaluated what needed to be evaluated. A pilot run was given to students in order to verify the clarity of the items. Then, and in keeping with recommendations by Díaz and Leyva (2013), the indices of difficulty of the problems were classified with the following results: over 0.9 the problem was considered to be easy, between 0.8 and 0.89 the problem was fairly easy, between 0.7 and 0.79 the problem was fairly difficult, between 0.5 and 0.69 the problem was quite difficult, and under 0.5 would be considered difficult problems. When the instrument was ready and after having defined the classification of indices of difficulty of the problems, a small group of six students taking the course of Mathematics for Business I was randomly chosen to take the exam. The reasoning behind the selection was based on the willingness of the students to participate in the study, to the fact that they had just studied the subject of linear functions in their class and to the fact that it was hoped that qualitative information of the processes students followed when answering the problem in the exam would be discovered.

Two 80-minute sessions were used for the students to answer the problems on the exam. Later the answers given by the students on the answer sheets were analyzed, the indices of difficulty were determined for each problem and the students' strengths and the areas of opportunity in relation to learning the linear function from the perspective of semiotic representations were identified.

\section{Results}

Table 1 shows the index of difficulty or proportion of students who correctly answered each item or problem on the instrument given to them. It can be seen that in the area of cognitive activity of Formation (Problems 1-8) students proved less efficient in the graphic register of linear function and more efficient in the tabular register. Three out of six graphic registers were difficult for the students to solve (1,2 and 5) and two others (3 and 6), were quite 
difficult. However, the two tabular registers ( 7 and 8 ) were fairly easy for the students.

Table 1. Index of difficulty of problems on semiotic registers reflected by the results of students on the exam

\begin{tabular}{|c|c|c|c|c|c|}
\hline \multirow[b]{2}{*}{ Item } & \multicolumn{2}{|c|}{ Register } & \multicolumn{2}{|c|}{ Index of difficulty } & \multirow[b]{2}{*}{ Task } \\
\hline & $\begin{array}{l}\text { Beginning } \\
\text { Final }\end{array}$ & Final & Intra & Cont & \\
\hline 1 & GRA & - & 0.33 & & Draw a Cartesian Plane including all of its elements. \\
\hline 2 & GRA & - & 0.33 & & Place seven points on the Cartesian Plane, given the coordinates. \\
\hline 3 & GRA & - & 0.66 & & $\begin{array}{l}\text { Place four points on the Cartesian Plane and recognize that they are in a } \\
\text { straight line. }\end{array}$ \\
\hline 4 & GRA & - & 1.00 & & Indicate the coordinates of a point located on a Cartesian Plane. \\
\hline 5 & GRA & - & & 0.33 & Place two points on a Cartesian Plane and connect them with a straight line. \\
\hline 6 & GRA & - & & 0.50 & Place the points of a table with known coordinates. \\
\hline 7 & $\mathrm{TAB}$ & - & & 0.83 & Identify the independent variable on a table, given the dependent variable. \\
\hline 8 & TAB & - & & 0.83 & Identify the independent variable on a table, given the dependent variable. \\
\hline 9 & GRA & GRA & & 0.16 & Locate a point on a system of axes, given its coordinates. \\
\hline 10 & GRA & GRA & & 0.33 & Determine the coordinates of a point, given the graph of a straight line. \\
\hline 11 & TAB & $\mathrm{TAB}$ & & 0.50 & Determine the values of $\mathrm{x}$ and $\mathrm{y}$, using a variation table. \\
\hline 12 & TAB & TAB & & 0.66 & $\begin{array}{l}\text { Determine the value of the gradient of a straight line from the values on a } \\
\text { table. }\end{array}$ \\
\hline 13 & TAB & $\mathrm{TAB}$ & & 1.00 & $\begin{array}{l}\text { Determine the value of } y \text { on a variation table and the value of } y \text { from a given } \\
\qquad x .\end{array}$ \\
\hline 14 & TAB & $\mathrm{TAB}$ & & 0.66 & Determine several values of $x$ knowing their $y$ values. \\
\hline 15 & $\mathrm{TAB}$ & $\mathrm{TAB}$ & & 0.83 & $\begin{array}{l}\text { Determine the value of } y \text { from } x \text {, and the coordinates of several points on a } \\
\text { table. }\end{array}$ \\
\hline 16 & TAB & $\mathrm{TAB}$ & & 0.83 & Determine the value of $y$ from the known value $x$. \\
\hline 17 & TAB & $\mathrm{TAB}$ & & 0.83 & Identify changes in $\mathrm{y}$ from changes in $\mathrm{x}$ from a table. \\
\hline 18 & $\mathrm{TAB}$ & $\mathrm{TAB}$ & & 0.83 & Determine the value of change in $\mathrm{y}$ if the change in $\mathrm{x}$ is known from a table. \\
\hline 19 & ALG & ALG & & 0.50 & $\begin{array}{c}\text { Determine the value of } \mathrm{y} \text { for a point knowing the value of } \mathrm{x} \text {, using algebraic } \\
\text { equations. }\end{array}$ \\
\hline 20 & TAB & ALG & 0.00 & & $\begin{array}{l}\text { Find the equation of a straight line if the coordinates of four points are } \\
\text { known. }\end{array}$ \\
\hline 21 & ALG & GRA & 0.00 & & Determine the graph of a straight line from its algebraic expression. \\
\hline 22 & GRA & ALG & 0.00 & & Determine the algebraic expression of a straight line from its graph. \\
\hline 23 & GRA & ALG & & 0.50 & Determine the equation of a straight line given significant points on a graph. \\
\hline 24 & $\mathrm{TAB}$ & ALG & & 0.66 & Determine the algebraic expression of a straight line from data on a table. \\
\hline
\end{tabular}

Note. Intra=Intra-mathematical problem; Cont=problem in context; $\mathrm{TAB}=$ tabular register; $\mathrm{ALG}=$ algebraic register; GRA=graphic register.

In relation to the cognitive activity of Treatment, it was found that the worst performance was in the graphic register and the best in the tabular register. The two problems about graphic Treatment ( 9 and 10) were especially hard for students since their indexes of difficulty were 0.16 and 0.33 , respectively while the eight problems related to tabular Treatment (11-18) were easier for the students. One was an easy problem (13), four were classified as fairly easy problems (15-18) and only three of the eight were quite difficult (11,12 and 14). The algebraic problem of Treatment (19) showed that for the students figuring out a Treatment problem of this kind was quite difficult.

In the section on the cognitive activity of Conversion the students had poor performance. In three out of the five problems $(20,21$ and 22) the students could not solve the problems: their index of difficulty was zero. Only some of the students answered the other two problems (23 and 24), with indexes of difficulty of 0.5 and 0.66 , respectively, classifying them as quite difficult. It is important to point out that this cognitive activity presented differentiated performance. Performance was better in problems within a context, compared to those within a strictly intra-mathematical context. See problem 23 vs 22 and 24 vs 20 .

Here is one of the typical answers given by students with respect to one of the intra-mathematical problems: "Given the following graph, which of the following equations applies? Justify your answer." The student was to relate the straight-line graph with one of the four equations given as options. It can be observed that the student 
managed to identify the equation based on the following affirmation: "the answer is $\mathrm{C}$ because upon giving $\mathrm{x}$ values these results in the points on the y axis" (Figure 1).

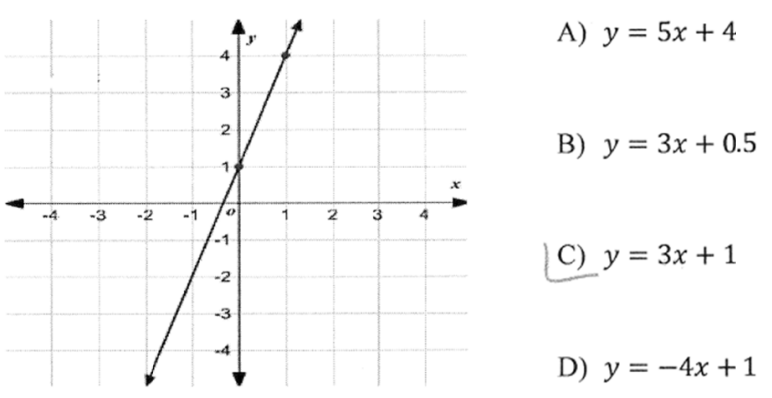

Figure 1. A student's answer to problem 22, an intra-mathematical problem

The student's answer shows his inability to read the graph and the lack of a relation he sees with the coefficients of the equation, specifically, with the coefficient $x$ of the equation which represents the slope of the straight line. In Duval's terms, this would be a lack of cognitive activity of Conversion between the graphic and the algebraic register.

\section{Discussion}

The results show that managing the graphic register of the linear function is the most difficult representation for students, regardless of the cognitive activity they are asked to carry out. This finding is in keeping with the study carried out by Prada-Núñez et al. (2017) in which the first-year students at a university showed signs of poor performance in managing the graphic register of functions in both Treatment and Conversion activities. Diaz et al. (2013) found similar results in first-year university students when they were asked to make algebraic graphs of linear functions. In their work these researchers found that most of the students could not come up with an error-free structure of their representations.

With regard to cognitive activity, of the three studied, the Conversion of linear function was the most difficult for the students, specifically between graphic and algebraic registers, algebraic and graphic and tabular to algebraic registers. The result proves the poor comprehension that students of mathematics have achieved up to now (Duval, 2006, 2012b), despite the fact that linear function was a subject which had been studied over and over again in math classes before reaching the university level. It must be pointed out that, upon analyzing the problems, it was found that some of the students did not find carry out any Conversions naturally but rather used alternate procedures for avoiding the obstacle and coming up with the result. For example, in a Conversion from the graphic to the algebraic register, they did not find the significant units of the graphic register of the linear function to form the algebraic representation, but rather tried each option one by one until they found the answer, by trial and error, which for Duval $(1993,2012 b)$ does not truly represent a Conversion from the graphic to the algebraic registry and thus the conceptual mastery of the mathematical object. Studies such as those of Amaya and Sgreccia (2014) make it apparent that on occasion students look for alternatives to carry out or check Conversions, not necessarily in the sense that they were asked to.

Other studies have similarly shown the low level of students' proficiency in Conversions of registers in the field of functions. For example, Díaz et al. (2013) reported that beginning university students made many mistakes in Conversions of linear and quadratic functions of an algebraic register to a graphic register and vice versa. Amaya and Sgreccia (2014) reported poor performance in Conversions of tabular registers to algebraic registers and from algebraic registers to graphic registers in students who were about to enroll in university. Likewise, in a study carried out by Panaoura et al. (2017), it was found that high school students faced serious difficulties when carrying out Conversions in different registers of function when solving problems. Martínez et al. (2016) in a diagnosis of semiotic skills of university students also reported serious deficiencies in carrying out Conversions from graphic to algebraic registers of basic mathematical subjects. In a recent study carried out by Campeón, Aldana, and Villa (2018) it was found that the most difficulty in learning the linear function was in transferring from one semiotic representation to another, especially, between the algebraic and graphic registers.

One interesting finding of our study was better performance of students in Conversions of registers in questions which were within context problems compared to those in an intra-mathematical context. This leads one to believe that, apparently, working with situations which are related to student's experience and/or activities favors the 
understanding of mathematical objects. This is in keeping with Tocto and Reaño's (2017) conclusions in their study on pre-university students' understanding of the properties of the quadratic function. The advantage this kind of problem poses for students may be due to the context which favors the connection of the mathematical object with real-life situations or contexts within students' university life, which allow the students to provide a sense, significance and application to what they are learning (Camarena, 2013; Trejo-Trejo et al., 2013).

An additional finding of the present research which should be pointed out has to do with the better performance shown by students in the Treatment of the linear function of the tabular register. This result contrasts with studies carried out by Martínez et al. (2016) and Amaya and Sgreccia (2014). This leads one to assume that probably teaching-learning activities pay special attention to this register over the others, contrary to what is said in specialized literature in that mathematical teaching at the university level generally revolves around the algebraic register (Martínez et al., 2016).

The results shown up to now invite one to reflect on the practices of teaching linear function. Emphasis should not be put on one sole register, nor should the attention be placed on a cognitive activity which is less complex than Conversions since we have seen that students can prove quite clever in performing Treatments in various registers of linear function and still having little real conceptual mastery of the mathematical object (Adu-Gyamfi \& Bossé, 2014). If our intention is to improve the understanding of linear function, then teaching should present learning approaches in which students reflect on cognitive activities of the Conversion of various semiotic representation of the object studied, as established by Duval (2006) and also shown in the study made by McGee and Martínez-Planell (2014). In so doing, students' skills for problem solving in the field of functions will also be strengthened. According to Elia et al. (2008), the use of various forms of representation of mathematical objects is closely associated with the skill of problem solving. In addition, it is also recommended that teachers direct their students' attention to the key properties of the functions, since these are what students recognize and use for successfully carrying out their Conversions, according to a study by Thomas, Wilson, Corballis, Lim, and Yoon (2010).

The poor results in activities of Conversion among various semiotic registers used in the present study clearly point to an important area of opportunity for the teaching/learning process on the subject of linear function and the course in general. If the student does not have mastery of Conversions, it means that the mathematical object has not been fully learned. This leads us to a call for further studies based on the contributions of research in the field of mathematical education reviewed here.

\section{Conclusions}

The study managed to determine the difficulties students of administration encountered in learning the concept of linear function, based on the registers of semiotic representation. In terms of registers and considering the three cognitive activities, it was discovered that the most difficulty was encountered in problems involving the graphic register. In relation to cognitive activity, the answers showed the students had the most difficulty in Conversion type transformations, leading us to understand that the concept of linear function is not thoroughly understood by students. It was also found that students' best performance was in the area of problems on the Treatment of tabular registers over the other representation.

Seemingly, situation problems of semiotic representations within contexts favor better performance, and thus a better understanding of the mathematical object. Therefore, stressing in the teaching process didactic sequences which improve these kinds of problems and also working purposefully with the following semiotic representations of the object under study: verbal, tabular, graphic and algebraic is recommended, emphasizing bidirectional Conversions to promote deeper understanding, directing student's attention to the key properties of functions in order to strengthen their skills for transferring between various representations.

We also suggest diagnoses similar to the present be carried out in relation to other subjects students take in the area of Business Mathematics I, in order to provide information on the state of learning results and with these in hand to come up with proposals for improving students' learning.

\section{References}

Adu-Gyamfi, K., \& Bossé, M. (2014). Processes and reasoning in representations of linear functions. International Journal of Science and Mathematics Education, 12(1), 167-192. https://doi.org/10.1007/s10763-013-9416-x

Amaya, T., \& Sgreccia, N. (2014). Dificultades de los estudiantes de once grados al hacer transformaciones de representaciones de una función. Épsilon, 31(88), 21-38. Retrieved from http://thales.cica.es/epsilon/sites/thales.cica.es.epsilon/files/\%5Bfield_volumen-formatted\%5D/epsilon $88 \_2$ 
.pdf

Camarena, P. (2013). A treinta años de la teoría educativa "Matemática en el Contexto de las Ciencias". Revista Innovación Educativa, 13(62), "17-44. $\quad$ Retrieved from http://www.scielo.org.mx/pdf/ie/v13n62/v13n62a3.pdf

Campeón, M., Aldana, E., \& Villa, J. (2018). Ingeniería didáctica para el aprendizaje de la función lineal mediante la modelación de situaciones. Sophia, 14(2), 115-126. https://doi.org/10.18634/sophiaj.14v.2i.629

Consejo de Acreditación de Ciencias Administrativas, Contables y Afines. (n.d.). Acreditación. Retrieved from http://caceca.org/acreditaciones/

Díaz, M., Haye, E., Montenegro, F., \& Córdoba, L. (2013). Dificultades de los alumnos para articular representaciones gráficas y algebraicas de funciones lineales y cuadráticas. In Y. Morales, \& A. Ramirez (Eds.), Memorias I CEMACYC (pp. 1-13). Santo Domingo, Dominican Republic: CEMACYC.

Díaz, P., \& Leyva, E. (2013). Metodología para determinar la calidad de los instrumentos de evaluación. Revista Educación Médica Superior, 27(2), 269-286. Retrieved from http://www.medigraphic.com/pdfs/educacion/cem-2013/cem132n.pdf

Duval, R. (1993). Registres de représentation sémiotique et fonctionnement cognitif de la pensée. Annales de Didactique et de Sciences Cognitives (Vol. 5, pp. 37-65). Strasbourg, France: Université de Strasbourg.

Duval, R. (2006). A cognitive analysis of problems of comprehension in a learning of mathematics. Educational Studies in Mathematics, 61(1), 103-131. https://doi.org/10.1007/s10649-006-0400-z

Duval, R. (2012a). Preguntas y desafíos de la enseñanza de las matemáticas para todos: implicaciones para la investigación en didáctica. In U. Malaspina (Ed.), Resúmenes del VI Coloquio Internacional de Didáctica de las Matemáticas: avances y desafios actuales (pp. 3-6). Lima, Peru: Pontificia Universidad Católica del Perú.

Duval, R. (2012b). Lo esencial de los procesos cognitivos de comprensión en matemáticas: los registros de representación semiótica. In U. Malaspina (Ed.), Resúmenes del VI Coloquio Internacional de Didáctica de las Matemáticas: avances y desafios actuales (pp. 14-17). Lima, Peru: Pontificia Universidad Católica del Perú.

Elia, I., Panaoura, A. Gagatsis, A. Gravvani, K., \& Spyrou, P. (2008) Exploring Different Aspects of the Understanding of Function: Toward a Four-Facet Model. Canadian Journal of Science, Mathematics and Technology Education, 8(1), 49-69. https://doi.org/10.1080/14926150802152277

Hernández, S., Fernández, C., \& Baptista, L. (2014). Metodología de la Investigación (Sexta edición). México: McGraw-Hill.

Márquez-Jiménez, A. (2017). A 15 años de PISA: Resultados y polémicas. Perfiles Educativos, 39(156), 3-15. https://doi.org/10.22201/iisue.24486167e.2017.156.58280

Martínez, G., Sevilla, J., Fuentes, M., Rivera, R., \& Ávila, R. (2016). Diagnóstico sobre habilidades semióticas matemáticas básicas en estudiantes de ingeniería. Ingenierías, 19(73), 7-14. Retrieved from http://www.ingenierias.uanl.mx/73/index.html

McGee, D., \& Martinez-Planell, R. (2014). A study of semiotic registers in the development of the definite integral of functions of two and three variables. International Journal of Science and Mathematics Education, 12(4), 883-916. https://doi.org/10.1007/s10763-013-9437-5

Ministerio de Educación. (n.d.). La importancia de enseñar y aprender matemática. Retrieved from http://web.educacion.gob.ec/_upload/10mo_anio_MATEMATICA.pdf

Panaoura, A., Michael-Chrysantho, P., Gagatsis, A., Elia, I., \& Philippou, A. (2017). A Structural Model Related to the Understanding of the Concept of Function: Definition and Problem Solving. International Journal of Science and Mathematics Education, 15(4), 723-740. https://doi.org/10.1007/s10763-016-9714-1

Prada-Núñez, R., Hernández-Suárez, C. A., \& Jaimes-Contreras, L. A. (2017). Representación semiótica de la noción de función: concepciones de los estudiantes que transitan del Colegio a la Universidad. Panorama, 11(20), 34-44. https://doi.org/10.15765/pnrm.v11i20.1008

Santibañez, J. (2011). Manual para la evaluación del aprendizaje estudiantil. Mexico: Trillas.

Secretaría de Educación Pública. (2018). Planea, resultados nacionales 2017. Retrieved from http://planea.sep.gob.mx/content/general/docs/2017/ResultadosNacionalesPlaneaMS2017.PDF 
Thomas, M., Wilson, A., Corballis, M. Lim, V., \& Yoon, C. (2010). Evidence from cognitive neuroscience for the role of graphical and algebraic representations in understanding functionl. ZDM Mathematics Education, 42(6), 607-619. https://doi.org/10.1007/s11858-010-0272-7

Tocto, E., \& Reaño, C. (2017). Comprensión de las propiedades de la función cuadrática mediada por los registros algebraico y gráfico. Revista de Produção Discente em Educação Matemática, 6(1), $50-59$. Retrieved from https://revistas.pucsp.br/index.php/pdemat/article/view/32567/22503

Trejo-Trejo, E., Camarena-Gallardo, P., \& Trejo-Trejo, N. (2013). Las matemáticas en la formación de un ingeniero: La matemática en contexto como propuesta metodológica. Revista Docencia Universitaria, 11, 397-424. https://doi.org/10.4995/redu.2013.5562

\section{Copyrights}

Copyright for this article is retained by the author(s), with first publication rights granted to the journal.

This is an open-access article distributed under the terms and conditions of the Creative Commons Attribution license (http://creativecommons.org/licenses/by/4.0/). 